\title{
Universal Banking Post Crisis: Past and Future of International Corporate and Personal Banking
}

\author{
Fernando B. Sotelino ${ }^{1, *}$, Rodrigo B. Gonzalez ${ }^{2}$ \\ ${ }^{1}$ School of International and Public Affairs, Columbia University, USA \\ ${ }^{2}$ Financial System Regulation Department at Central Bank of Brazil, Brazil
}

Copyright $\mathrm{O} 2016$ by authors, all rights reserved. Authors agree that this article remains permanently open access under the terms of the Creative Commons Attribution License 4.0 international License.

\begin{abstract}
This paper reviews the characteristics of the international incursions by banks since the early 1990s, examines the implications of the US subprime meltdown crisis and ensuing credit crunch for the pursuit of international banking activities, and provides a conceptual framework to help banks assess strategic decisions regarding the scope of their international operations in the years to come. We conclude that international banks, while remaining loyal to universal banking in terms of scope of activities, should become increasingly selective regarding the international reach of each and all components of their financial services offering portfolio.
\end{abstract}

Keywords Wholesale Bank, Universal Bank, Personal Banking, Wealth Management

JEL Classification: G18, G21, G28.

\section{Introduction}

The 1990s were a period of fast expansion and re-invention for the banking industry globally. The three main factors affecting the fundamentals of financial intermediation that caused this re-invention were major regulatory changes, an extraordinary acceleration in the use of digital technology, and the explosive growth of the securities markets.

On the regulatory front, a process of financial liberalization came about almost simultaneously on both sides of the Atlantic. In Europe, the Financial Services Action Plan (1999) formalized a series of measures towards a single wholesale financial market and a more open retail market in the European Union, completing a process of gradual reduction of barriers to cross-border financial intermediation initiated ten years prior with the EU Second Banking Directive of 1989 (Dermine, 2002). In the U.S., over six decades of regulatory obstacles to interstate banking and universal banking were removed. In 1994, The Riegel-Neal Interstate Banking Act revoked the restrictions to interstate mergers among banks which had been put in place by the McFadden Act in 1927; and, in 1999, The Gramm-Leach-Bliley Act (or The Bank Holding Company Act) completed the elimination of regulatory constraints to securities underwriting activities by commercial banks originally set in place by The Glass-Steagall Act in 1933 (Bodie, 2005).

On the technological front, substantial acceleration of a paper-to-digital trend revolutionized how financial information was assembled and disseminated. Assessment, classification, bundling and securitization of credit risk, monitoring of contractual obligations and secure execution of trades became much cheaper and faster.

Finally, and very much facilitated by the above, explosive growth of the securities markets exerted downward pressure on the spreads commercial banks could earn on better known credit risks. Their response was to engage in the pursuit of, both, capital markets activities and higher margin consumer finance endeavors, often through acquisitions at home and abroad.

This long period of a purely market driven broadening of scope and geographic reach of activities by leading banks around the globe was to come to a halt in 2008. The U.S. subprime meltdown crisis and ensuing global credit crunch combined to trigger, first, a process of government assisted financial industry consolidation in many countries and, subsequently, a profound re-examination of bank regulations. New rules have been enacted and gradually enforced by jurisdictions around the world that call for more and better quality loss absorbing bank capital, explicit minimum liquidity and stability of funding requirements, and tighter guidelines regarding trading book capital allocations. In addition, specific restrictions to the engagement by depositary financial institutions in certain types of activities have been put in place.

In the following sessions we examine the process of internationalization of universal banks pre and post the 2008 financial crisis, present a conceptual framework for decision-making by banks regarding the scope of their international operations, and conclude with a prospective 
view for universal banking in the years to come.

\section{From Corporate Commercial to Wholesale Banking}

The explosive growth of the securities markets from the mid-1980s onwards had the effect of increasing the competition for high quality corporate credits. Increased demand by institutional investors (pension funds, insurance companies, asset managers, and hedge funds) put downward pressure on the spread banks could charge for corporate credit risk (Crosse et al, 1973). As a result, balance sheet carry of institutional credit risk - the core source of revenues for the traditional corporate commercial bank - gradually became less and less financially rewarding (Marshall et al, 1994).

The response by most leading corporate commercial lenders was to seek to lever on their access to - and understanding of the credit risk of - institutional clients to pursue the investment banking activities of securities underwriting. Some banks, such as JPMorgan (JPMorgan, 2012) chose to build the most critical missing piece, access to investors - or securities sales and distribution - from within. Other commercial banks chose to acquire investment banks, the first notable one being Credit Suisse's purchase of $44 \%$ equity ownership of First Boston for US\$ 1.1 billion in October 1988 (Sterngold, 1988).

Exhibit 1 presents a sample list of investment banks and/or broker-dealers acquired by commercial banking franchises before the 2008 financial crisis.

Financial services offered to large corporations are also demanded by government entities and other financial institutions. As a result, most banks have eventually converged to group these institutional customers into a major single coverage umbrella, the wholesale bank (Apostolik et al, 2009), be it called Institutional Clients Group (Citicorp), Corporate and Investment Bank (BNP Paribas and Deutsche Bank), Wholesale Banking (TD and Wells Fargo) or, simply, Investment Bank (JPMorgan Chase).

\section{From Domestic to International Personal Banking}

Until the early 1980's banks tended to divide the coverage of their individual customer base in, essentially, two major groups, consumer bank and private bank. The consumer bank would serve the public-at-large; the private bank would offer the personalized attention of specialized executives to high net-worth individuals and families (Sinkey, 1998).

Individuals' financial services needs combine the demands for payment services ( checking accounts and debit cards), credit products (such as overdraft accounts, personal, auto, mortgage and home equity loans, credit card facilities), investment products (such as savings accounts, brokerage services, investment funds), and insurance (such as auto, home, health and retirement). The challenge for the financial institution is to establish and effectively manage the mix of personal banking products that can most efficiently capture the profit potential from its serving of constituencies with different characteristics and priorities (DiVanna, 2004).

Exhibit 1. Commercial Banks’ Acquisitions of Investment Banks, 1989 - 2006

\begin{tabular}{|cc|c|c|c|c|}
\hline \multicolumn{2}{|c|}{ Year (Value, US\$ bi)) } & Acquirer & Country & Target & Country \\
\hline 1989 & $(\$ 1.5)$ & Deutsche Bank & Germany & Morgan Grenfell & U.K. \\
\hline 1995 & $(\$ 1.5)$ & Dresdner Bank & Germany & Kleinworth Benson & U.K. \\
\hline 1995 & $(\$ 1.0)$ & ING & Netherlands & Barings & U.K. \\
\hline 1997 & $(\$ 1.2)$ & Nations Bank & U.S. & Montgomery Secs & U.S. \\
\hline 1997 & $(\$ 1.7)$ & Bankers Trust & U.S. & Alex Brown & U.S. \\
\hline 1998 & $(\$ 1.4)$ & SBC & Switzerland & Warburg D. Read & U.K. \\
\hline 1998 & $(\$ 0.7)$ & Credit Suisse & Switzerland & Banco Garantia & Brazil \\
\hline 1999 & $(\$ 1.4)$ & Chase Manhattan & U.S. & Hambrecht \& Quist & U.S. \\
\hline 1999 & $(\$ 10.0)$ & Deutsche Bank & Germany & Schroder & U.K. \\
\hline 2000 & $(\$ 2.2)$ & Citigroup & U.S. & DLJ & U.S. \\
\hline 2000 & $(\$ 11.5)$ & Credit Suisse & Switzerland & Paine Webber & U.S. \\
\hline 2000 & $(\$ 12.0)$ & UBS & Switzerland & R. Flemings & U.S. \\
\hline 2003 & $(\$ 7.7)$ & Chase Bank & U.G. Edwards & U.S. \\
\hline 2006 & $(\$ 6.8)$ & Uachovia & Banco Pactual & Brazil \\
\hline 2006 & $(\$ 2.6)$ & Switzerland & & & \\
\hline
\end{tabular}

Source: by author, from newspaper clippings (NYT, WSJ, FT, Reuters, Bloomberg) 
In response to this challenge, banks have continuously sought to refine their personal banking segmentation strategies (Venzin, 2009). In consumer banking, sub-segmentation tends to be guided by the customers' income level, as a proxy for their likely demand for credit and ability to borrow. In private banking, sub-segmentation is primarily determined by the customers' net-worth, as a proxy for their likely demand for wealth management assistance and willingness to invest. The explosive growth of the securities markets globally over the past two decades has had the effect of making global wealth management an absolute priority for the private bank. At the same time, rich profit margins from domestic consumer lending led several banks to more aggressively pursue the establishment of retail banking overseas.

These two movements are described below.

\section{International Private Banking}

Until the late 1980s, high net-worth individuals had sought international private banking relationships with the primary objective of protection of their wealth from domestic turmoil and/or regulatory scrutiny. However, a shift on their preferences took towards greater portfolio diversification and higher yields took place since then. This shift was the result of the same forces that transformed corporate and investment banking mentioned above plus the stimulus of specific actions taken by governments around the world to enact legislation and tighten bank regulations against tax evasion and avoidance mechanisms (Croft, 2010). These banks must now be able to offer their clients also the services of third party providers of investment management and insurance products.

Client coverage is typically organized along two main dimensions, region of origin and size of net-worth (Maude, 2005). Other criteria, more directly related to potential revenues to be generated - such as account size and amount of investable assets - help the financial institution to further sub-segment further (e.g. high, ultra-high and mega-high), typically allocating a smaller number of customers of higher revenue potential to its more seasoned private bankers.

Competition for wealth management fees is fierce and players are not only the world's largest international banks but also non-bank providers of investment advice and brokerage services (e.g. Fidelity, Charles Schwab) as well as leading regional private sector banks (e.g. Nordea, Itau-Unibanco). The resulting downward pressure on margins in private banking has served as an incentive for increased cooperation between private banking and investment banking divisions. First, the cost of support functions (such as compliance, marketing, sell-side research) can be shared. Secondly, business origination can be improved, as private bankers and investment bankers cooperate to cross-sell the institutions capabilities in each arena to bring in the most attractive advisory mandates. UBS and Credit Suisse already acknowledged evidence of this trend in their 2011 annual reports (see below).
The Investment Bank is critical to the success of UBS's strategy... We are repositioning the Investment Bank to align our businesses more closely with the needs of our core clients and the wealth management franchise and to address economic and regulatory changes that affect the entire industry (UBS AG. 2011. Form 20-F Annual Report of 2011, pp. 77).

Due to the capabilities of our integrated business model, the ultra-high-net-worth client segment represents a key growth area for Credit Suisse... In investment banking, we have also taken steps to evolve our business model: We are investing in growing businesses where we have clear competitive advantages and can exploit synergies with our Private Banking and Asset Management businesses (Credit Suisse Group AG. 2011. Form 20-F Annual Report of 2011, Letter to shareholder).

\section{International Consumer Banking}

The main obstacle for a bank considering entry into a foreign consumer banking market is the existence of well entrenched financial institutions that already enjoy the advantages of a significant distribution network, a trusted brand, as well as cultural integration with the customer base.

Differently from wholesale and private banking - where the customer perceives the foreign bank as a passport to the world - going abroad in consumer banking requires from the incoming institution that it become a domestic bank overseas. Not surprisingly, entry by a consumer bank institution into a new market typically takes place through the acquisition of a local franchise.

Three main factors drove a more aggressive stance by certain banks towards consumer banking abroad from the late 1980s onwards. They were: (i) technological breakthroughs, which facilitated automated contracting, settlement and control of financial transactions and allowed for a much lower distribution cost for retail banking services; (ii) the combination of attractive margins with the apparent reliability of consumer behavior and credit models (Mays, 2004); and (iii) the lowering in many countries of regulatory restrictions to the acquisition of major domestic consumer banking franchises by foreign banks.

This balancing act between the attractiveness of margins versus the challenge associated with the establishment of viable scale operations overseas has led most banks to take regional approaches (Fiordelini, 2009) to international consumer banking. Examples of this phenomenon were the moves of BBVA/Spain towards Latin America, Commerzbank/Germany and UniCredit/Italy towards Central European countries (early 2000s), and Citibank/US towards Mexico (2001).

Until 2008, only two banks had chosen to pursue a more global approach to consumer banking and in doing so, only taking a more aggressive stance towards a new region after the consolidation of strong market positions in a previous one. These were the cases of $\mathrm{HSBC} / \mathrm{UK}$ towards the 
Americas from the late 1990s onwards (Patil et al, 2007), after having achieved strong competitive positions in many countries in Asia and of Banco Santander/Spain towards the U.S. and the U.K. in the early 2000s (Ghemawat et al, 2006), after consolidation of strong consumer banking positions in many countries in Latin America.

It is worth mentioning that very low funding costs for banks between 2001 and 2006 (resulting, primarily, from historically low interest rates in the U.S.) combined with historically high demand for consumer credit further enticed the appetite of banks for consumer lending. Important transactions from this period were the acquisitions of Household Finance (U.S.) and Losango (Brazil) by HSBC in 2002 (HSBC Holding plc., 2002) and of Abbey National (U.K.) by Banco Santander in 2004 (Banco Santander S.A., 2004).

This long period of aggressive market driven pursuit by leading commercial banks around the world of, both, broader scope of activities (from commercial corporate and personal banking to universal banking, encompassing corporate banking, investment banking, private banking, asset management, commercial retail banking, consumer finance, and, in some cases, insurance) and greater geographic reach (from domestic to regional to increasingly international to, possibly, global) would come to a jolt in 2008. After 2008, lack of confidence by financial institutions around the world on the financial health of each other froze interbank credit, severely affecting credit availability to businesses and consumers in many domestic jurisdictions around the world as well as the fixed income and equity securities markets globally.

One indicator of the magnitude of the global credit contraction was the abysmal drop in syndicated loan volume in OECD countries, from US\$ 1.2 trillion in the third quarter of 2007 to under US\$ 400 billion in the first quarter of 2009 (Chui, 2010).

\section{Government Response to the Crisis}

\section{IMMEDIATE Response (2008-2009)}

The immediate response by governments around the world to avoid the collapse of their financial systems was a combination of increased government backing of bank deposits, liquidity assistance by central banks in their jurisdictions and, where immediately necessary, direct intervention by national treasuries - at tax payers'expense in major affected institutions.

This treasury backed assistance to major severely affected FIs - later to be characterized under Basel III as either systemically important financial institution (SIFIs) or domestic systemically important financial institutions (D-SIFIs) took fundamentally two forms:

a) Recapitalization of troubled financial institutions typically through purchase by national treasuries of convertible preferred stock - with de facto takeover of management control. Those were the cases for Fannie Mae,
Freddie Mac and AIG in the US (September 2008); Royal Bank of Scotland (RBS), Lloyds Bank and HBOS in the UK (October 2008); Allied Irish Bank, Bank of Ireland and Anglo Irish Bank, Ireland's three largest banks (February 2009); Kaupting, Glittnir and Landsbanki, Iceland's three largest banks (October 2008).

b) Recapitalization of troubled financial institutions without a government takeover of management control, among which: US banks under the Troubled Assets Relief Program (TARP - approved by Congress in October 2008), most ostensibly, Citibank (November 2008) and Bank of America (early 2009); UBS (Switzerland, October 2008); ING (Deutschland, October 2008); and Commerzbank (Germany, Nov 2008).

\section{REGULATORY DEVELOPMENTS (2009-current)}

Recognition globally that excessive leverage, over-reliance on short-term funding and inadequate supervision by bank regulators had been at the root of the quasi collapse of the financial system led to a major revamping of bank regulation.

The new regulations already issued and in force, proposed and/or under discussion can be bundled in two major categories: Basel II.5 and III, and Beyond Basel III.

Basel III, proposed in June 2011 by the Basel Committee on Bank Supervision (BCBS), represented a severe tightening of the previously prevailing Basel II regulatory standards. In addition, it imposed two new financial standards, minimum liquidity and maximum nominal leverage (BIS, June 2011).

Under Basel III, the set of financial requirements for banks to be implemented by regulators around the world in their individual geographic jurisdictions until 2019 can be summarized as follows (refer to Annex 1 for a more detailed perspective on Basel III and comparisons with Basel I and II):

i. minimum common equity as a percentage of total risk weighted assets of 7\% (up from $2 \%$ under Basel II) of total risk-weighted assets (TRWA); plus up to $2.5 \%$ of TRWA (as a minimum countercyclical buffer to be imposed at the discretion of individual jurisdictions on banks under their supervision); plus an additional loss absorbency capacity of up to $3.5 \%$ of TRWA for systemically important financial institutions (SIFIs), as such identified by the BCBS upon consideration of five characteristics - size, cross jurisdictional activity, interconnectedness, substitutability, and complexity (BIS, November 2011).

ii. minimum Liquidity Coverage Ratio ( $L C R$ ), aimed at ensuring banks' resilience to survive a 30-day stress scenario of eroded liquidity, and minimum Net Stable Funding Ratio (NSFR), aimed at limiting banks' over-reliance on potentially unstable short-term funding;

iii. higher capital charges for off-balance sheet and derivatives exposures; and 
iv. maximum total leverage, through the requirement of minimum equity of $3 \%$ of total non-risk-weighted (or notional) assets.

Whereas the Basel III framework is in phase-in gradually until 2019, certain changes directed at strengthening trading book capital requirements (particularly for securitized instruments) were implemented sooner (in 2010), therefore called Basel II.5.

Other efforts targeted at preventing too big to fail defined as situations when a financial institution has to be bailed-out at tax payers' expense - included the enactment of specific pieces of legislation that curb certain risk taking activities by banks and facilitate the timely intervention on and orderly liquidation of SIFIs. These measures can be summarized as follows:

i. restrictions to over-the-counter (OTC) derivatives trading that go beyond Basel III's higher capital requirements, with the effect of pushing certain types of trades to central clearing platforms (CCPs);

ii. explicit limitations to proprietary trading by banks (Volcker Rule in the U.S., Separate Legal Entity in EU; Ring Fence in the UK);

iii. frequent (at least annual) stress-testing of SIFIs' capital adequacy by their respective central banks (stress testing of capital adequacy is a recommendation to jurisdictional supervisors under the Basel III framework);

iv. obligation for SIFIs to develop and maintain resolution plans (or living wills) that provide regulators with a roadmap for the company's orderly liquidation without disruption to the financial system;

v. specific legislation empowering regulators to place a SIFI in orderly liquidation and conduct this process; and

vi. restrictions on incentive compensation, including the establishment of caps and claw back mechanisms for bonus payments to management and boards (mostly Liikanen report, EU).

While final rule making on several of these measures is still under debate, the consequences for internationally active banks are clear: substantially higher capital requirements overall and for securities trading and off-balance sheet exposures in particular; severally regulatory restrictions to proprietary trading; and, last but not least, much closer regulatory scrutiny and supervision.

\section{Private Sector Response to the Crisis}

The private sector response to the crisis has developed also in two clearly dusting stages, a government-assisted consolidation wave (2008-2009) and a purely market-driven adjustment wave (post 2010).

The government-assisted consolidation wave was characterized by a number of systemically important transactions contracted among private sector parties with upfront or contingent government support. The main transactions of this phase involving major international banks were:

a) The outright takeovers in the U.S. of important independent mortgage lenders and investment banks by some of the country's leading universal banks: Bear Stearns (investment bank) and Washington Mutual (mortgage lender), by JPMorgan; Countrywide (mortgage lender) and Merrill Lynch (investment bank), by Bank of America;

b) The recapitalizations of the two leading US investment banks, Goldman Sachs and Morgan Stanley, through high yield convertible preferred stock issues purchased by Berkshire Hathaway and Mitsubishi UFJ, respectively. These transactions, in the immediate aftermath of the Lehman Brothers' failure in September 2008, followed the conversion of the legal status of Goldman Sachs and Morgan Stanley from broker-dealers to bank holding companies ${ }^{1}$;

c) The absorptions in Europe of Dresdner Bank by Commerzbank (Germany, September 2008), of HBOS by Lloyds Bank (UK, January 2009), of Fortis by BNP Paribas (Belgium, March 2009), and of the mortgage lenders Alliance \& Leicester and Bradford \& Bingley by Banco Santander (UK, October 2008); and

d) Contracted contingent commitments to the divestment of certain subsidiary operations divestments, such as the one established between ING Groep and the Dutch government. ING Groep ended up divesting its ING-Direct operations in the US, UK and Canada, acquired by Capital One (US, 2011), Scotiabank (Canada, 2012), and Barclays (UK, 2013).

The market-driven adjustment phase has evolved very much in sync with the coming into force of the Basel III and beyond Basel III regulatory requirements discussed in section IV. It has consisted of selective divestments on non-core activities (mostly, although not exclusively); other capital preservation initiatives; and across the board cost cutting efforts.

Exhibit 2 below illustrates the importance of the divestment component of this market-driven adjustment phase for two international universal banks, HSBC and Citicorp. 
Exhibit 2. Market-Driven Adjustment Phase, Divestments 2011 - 2016

\begin{tabular}{|c|c|c|c|c|}
\hline Bank & Year & Divestment & Acquirer & Value (US\$ mm) \\
\hline HSBC & 2011 & Retail banking operations in Thailand & Ayudhya (Thai) & 115 \\
\hline & 2011 & Private banking operations in Japan & Credit Suisse & n.a. \\
\hline & 2012 & Domestic US credit card operation & Capital One (US) & 2,500 \\
\hline & 2013 & Retail banking in Central America & Bancolombia (Col) & 2,100 \\
\hline & 2015 & Retail banking operations in Brazil & Bradesco (Br) & 3,700 \\
\hline & 2012 & $10 \%$ equity stake HDFC (India) & group of investors & 1,900 \\
\hline & $2012-15$ & $20 \%$ equity stake in Akbank (Turkey) & group of investors & 2,300 \\
\hline & 2013 & Consumer finance operations in Brazil & Itau Unibanco (Br) & 1,370 \\
\hline
\end{tabular}

Source: by author, from newspaper clippings (NYT, WSJ, FT, Reuters, Bloomberg)

The market value shown in Exhibit 2 above captures only the amount paid by the buyer (in cash and/or stock) for the acquisition. From the standpoint of the seller, the overall balance sheet effect is the gain (or loss) associated with the divestment plus the reduction in total risk-weighted assets, with the resulting capital preservation for allocation elsewhere.

On the issue of capital preservation, cutbacks by banks in securities trading platforms have been often labeled by the media as a move away from investment banking, as in the quote below:

\section{"Across Europe, banking giants like Barclays, Deutsche Bank, UBS and Royal Bank of Scotland \\ have, to varying degrees, moved away from traditional investment banking activities because of increased regulation and volatile markets..."(Thomas, L., Credit Suisse Boss Faces Revolt From Bankers Over Strategy Shift, The New York Times, June 4, 2016)}

We would argue that what has been substantially affected by regulation is the capital charge associated with the inventory of securities a bank can carry, which affects the optimal size securities trading desks can have in terms of, both, capital and operating costs. This is not a trivial adjustment process for any institution, as it causes dislocation of people and compensation of those that remain (Thomas, 2016). But the ultimate objective of investment banking - to seek to match issuers and investors through the structuring and placement of securities (including derivative instruments), that meet their objectives and constraints - has not been abandoned. Much to the contrary, traditional investment banking remains central to the wholesale banking strategy of leading universal banks globally.

\section{Strategic Framework and Prospective View}

The combination of the government and private sector responses to-date to the crisis has resulted in an acceleration of the market driven process of concentration of the banking industry globally that had prevailed until 2008 .
It has also reinforced the trend for banks of different jurisdictions around the world towards universal banking including the U.S. where leading independent mortgage lenders and investment banks have been absorbed by universal banks, exception made to-date to Goldman Sachs and Morgan Stanley - now bank holding companies while not commercial banks.

The combination of new regulatory restrictions with lessons learned from the crisis are pushing banks' management and boards of directors to go beyond the non-core divestments of the sort illustrated in Exhibit 2 to obsessively pursue much more selective value driven business strategies in terms of, both, scope of activities and geographic reach.

Exhibit 3 below helps clarify the strategic thinking outlined above. As can be observed, we classify Scope of Activities in five categories - Retail, Wholesale and Private Banking, plus asset Management and Insurance; Geographic Reach, in four - Domestic, Regional, International, and Global; and Market Share also in four Leading, Important, Significant and Participant.

Exhibit 3 - Strategic Framework

\begin{tabular}{|c|c|c|}
\hline Scope of Activities & Geographic Reach & Scale/Market Share \\
\hline Retail Banking & & \\
\hline Individual Banking & & \\
\hline Consumer Finance & Domestic & Participant Credit Cards \\
\hline Credit Cards & & Significant \\
\hline SMEs & Regional & Important \\
\hline Wholesale Banking & & \\
\hline Commercial & International & Leading \\
\hline Bransaction Services & & \\
\hline Investment Banking & Global & \\
\hline Private Banking & & \\
\hline Asset Management & & \\
\hline Insurance & & \\
\hline
\end{tabular}


For the sake of illustration of the framework - and based on publicly available information - Citibank can be seen as a leading domestic universal bank, a leading global wholesale bank, and an important global private bank; HSBC, a leading domestic universal bank, a leading international retail bank, an important global wholesale bank, and a significant international private bank; and UBS, a leading domestic universal bank, a leading global private bank, and an important global investment bank.

The challenge for managements and boards is to properly assess their bank's strengths and weaknesses relative to the competition across the full spectrum of their company's Scope of Activities in each Geographic Arena under consideration. As a result, market positions that ensure acceptable and sustainable returns on thoroughly determined economic capital allocated for each initiative at each jurisdiction can be achieved.

This will most likely imply in continued domestic pursuit of leading positions across the entire spectrum of financial services to individual and institutional clients the financial institution chooses to engage in their home jurisdictions; but reserving regional/international ambition to a narrower second, and global reach for only an even narrower third set of financial service activities.

\section{Concluding Remarks}

Over the past three decades three major factors have combined to bring about fast expansion and a re-invention of the financial services globally: (i) major regulatory changes, facilitating the broadening of scope of activities of banks and their internationalization; (ii) the extraordinary technological evolution of the means through which financial transactions are contracted and settled; and (iii) the explosive growth of securities markets.

These forces caused corporate commercial banks to aggressively pursue investment banking activities, made global wealth management an absolute priority for the private bank, and also created incentives for much closer cooperation between private and investment banking in terms of, both, cost sharing of support functions and cross-sell of financial services. In addition, increasingly attractive margins of consumer financing activities resulting from particularly low funding costs for financial intermediaries and global economic growth between 2002 and 2007 caused banks to also pursue the acquisition of major consumer finance companies and/or mortgage lenders at home and abroad.

Most of the fundamental drivers of the trend towards universal banking observed in the almost three decades that preceded the 2008 U.S. subprime meltdown crisis, in particular the synergies between institutional lending and securities underwriting, and between investment banking and private banking, remain in place.

On the other hand, lessons learned by banks' boards of directors and significantly tighter regulations push banks to pursue well assessed and more selective value-driven business strategies in terms of scope of activities and geographic reach.

The challenge for banks around the world is to properly assess their companies' strengths and weaknesses across the full spectrum of their institutions' financial services offerings vis-à-vis those of the stronger competitors in each geographic arena under consideration, so that economically viable market shares can be achieved. In other words, to be capable of putting in place and sustaining an organization that can successfully pursue strong market positions - with virtually assured acceptable profitability - in all it chooses to do.

For major universal banks from countries around the world, this will most likely imply in continued domestic pursuit of leading positions across the full spectrum of their scope of activities; but also accepting regional, international and global reach in progressively narrower ranges of financial service activities.

\section{Annex 1. Basel I to Basel III}




\begin{tabular}{|c|c|c|c|}
\hline & Basel I & Basel II & Basel II.5 and Basel III \\
\hline Year & 1988 & 2004 & 2010 \\
\hline Context & $\begin{array}{c}\text { 1980s Bank crises in Latin } \\
\text { America }\end{array}$ & Asia and Russia Crisis of $1997 / 98$ & Subprime Meltdown 2008 \\
\hline Main Purpose & $\begin{array}{l}\text { Create Minimum Capital } \\
\text { requirements for credit risk }\end{array}$ & $\begin{array}{l}\text { Extend the framework to Operational } \\
\text { and Market risk }\end{array}$ & Liquidity, Leverage, Too-Big-to-Fail \\
\hline Credit Risk & Risk Weights Created & $\begin{array}{c}\text { Credit Risk becomes model } \\
\text { dependent or subject to CRAs } \\
\text { opinions }\end{array}$ & RWs for securitization are increased \\
\hline Market Risk & N.E. & $\begin{array}{c}\text { Introduced as Maturity Ladder } \\
\text { (Standard approach) or Model } \\
\text { dependent (IRB) }\end{array}$ & $\begin{array}{l}\text { Capital charges for securotization increase, } \\
\text { Stressed value-at-risk (sVaR) created, } \\
\text { counterparty credit risk is elevated and CVA is } \\
\text { introduced }\end{array}$ \\
\hline Operational Risk & N.E. & $\begin{array}{c}\text { Introduced as Supervisor Formula } \\
\text { (Standard approach) or Model } \\
\text { dependent (IRB) }\end{array}$ & No changes \\
\hline Liquidity risk & N.E. & N.E. & NSFR and LCR created \\
\hline Capital definition & $\begin{array}{l}\text { Core capital and Reserves } \\
\text { are the main Tier } 1 \text { capital }\end{array}$ & Tier 2 expanded & $\begin{array}{c}\text { Tier } 2 \text { is mostly phased-out. Tier } 1 \text { (non-core } \\
\text { capital instruments aremaid bailed-in or } \\
\text { Convertible) }\end{array}$ \\
\hline Capital Requirement & $\begin{array}{l}\text { Countries have discretion, } \\
\text { but } 8 \% \text { was suggested }\end{array}$ & $\begin{array}{c}\text { Countries have discretion, but } 2 \% \\
\text { core, } 4 \% \text { Tier } 1 \text { and } 4 \% \text { Tier } 2 \text { are } \\
\text { suggested }\end{array}$ & $\begin{array}{l}\text { For all G-20 countries, } 10.5 \% \text { (in } 2019 \text { ), } \\
\text { including a cons evation buffer. Composition } \\
\text { changes to: } 4 \% \text { Core Capital and } 7.5 \% \text { Tier } 1\end{array}$ \\
\hline Additional capital & N.E. & $\begin{array}{l}\text { Instrumentos híbridos de Capital e } \\
\text { Dívida se expandiram muito e foram } \\
\text { largamente usados. }\end{array}$ & $\begin{array}{c}\text { Up to } 2.5 \% \text { as a countercyclical buffer } \\
\text { (country discretion) and up to } 3.5 \% \text { to G-SIBS } \\
\text { (Systemic Banks are chosen by the BCBS) or D } \\
\text { SIBS (country discretion) }\end{array}$ \\
\hline
\end{tabular}

\section{REFERRENCES}

[1] Apostolik, A., Donohue, C. and Went, P. 2009. Foundations of Banking Risk. Hoboken, New Jersey: Wiley and Sons, Inc.

[2] Baker-Said, S. and Harper, C. 2006. Credit Suisse, Failing to Match First Boston Legacy Dumps Name, Bloomberg,

[3] Banco Santander, S.A. 2004. Form 20-F Annual Report of 2004. Retrieved from http://www.sec.gov/edgar.shtm

[4] Banco Santander, S.A. 2011. Form 20-F Annual Report of 2011. Retrieved from http://www.sec.gov/edgar.shtm

[5] Bank of America. 2011. Bank of America to Exit International Credit Card Businesses, Newsroom, August 16, 2011, Retrievedfromhttp://mediaroom.bankofamerica.com/phoenix .zhtml?c=234503\&p=irol-newsArticle\&ID=1596323\&highli ght

[6] Bank of America Corp. 2011. Form 10-K Annual Report of 2011. Retrieved from http://www.sec.gov/edgar.shtm

[7] Basel Committee on Banking Supervision - BCBS. 2011a. Basel III: A global regulatory framework for more resilient banks and banking systems. Document, July.

[8] Basel Committee on Banking Supervision - BCBS. 2011b. Global systemically important banks: assessment methodology and the additional loss absorbency requirement. Rules Text, Nov.

[9] Basel Committee on Banking Supervision - BCBS. 2013. Basel III: The Liquidity Coverage Ratio and liquidity monitoring tools. Retrieved from http://www.bis.org/publ/bc bs238.htm

[10] BNP Paribas. 2011. 2011 Annual Report. Retrieved from http://annualreport.bnpparibas.com/2011/

[11] Bodie, Z., Kane, A. and Marcus, A. 2005. Investments. New York: McGraw Hill 
[12] BTG Pactual. 2012. History, Retrieved From http://www.btgpactual.com/NonBrazilian/WhoWeAre.aspx/ OurHistory

[13] Capital One. 2011. 2011 Annual Report. Retrieved fromhttp://phx.corporate-ir.net/phoenix.zhtml?c=70667\&p=i rol-reportsannual

[14] Citigroup Inc. 2011. Form 10-K Annual Report of 2011. Retrieved from http://www.sec.gov/edgar.shtm

[15] Chatterjee, R. R. 2012. 'Dictionaries Fail: The Volcker Rule's Reliance On Definitions Renders It Ineffective And A New Solution Is Needed To Adequately Regulate Proprietary Trading', BYU International Law and Management Review, Retrieved from

http://www.law2.byu.edu/ilmr/articles/winter_2011/BYU_IL MR_winter_2011_3_Dictionaries.pdf

[16] Chui, M., Domanski, D., Kugler, P., and Shek, J. 2010. The collapse of international bank finance during the crisis: evidence from syndicated loan markets, BIS Quarterly Review, September 2010

[17] Credit Suisse Group AG. 2011. Form 20-F Annual Report of 2011. Retrieved from http://www.sec.gov/edgar.shtm

[18] Croft, J. 2009. Santander takes pole position as rivals languish in pits. Financial Times, Sep 27, 2009

[19] Croft, J. 2010. Compliance: IRS pushes banks to put pressure on tax evaders. Financial Times, Nov 9, 2010.

[20] Crosse, H. and Hempel, G. 1973. Management Policies for Commercial Banks. Englewood Cliffs, New Jersey: Prentice Hall.

[21] Davis, S. 2000. Bank Mergers - Lessons for the Future. New York: St. Martin's Press.

[22] DEALBOOK. 2008. Wells Fargo to Buy Wachovia in \$15.1 Billion Deal, The New York Times Oct 3, 2008.

[23] Dermine, J. 2002. 'Banking in Europe, Past, Present and Future' in The Transformation of the European Financial System, eds. Gaspar, Hartmann and Sipjen, ECB, Oct.

[24] Deutsche Bank Corp. 2011. Form 20-F Annual Report of 2011. Retrieved from http://www.sec.gov/edgar.shtm.

[25] Deutsche Bank UK. 2012. History, Website retrieved from ttps://www.db.com/unitedkingdom/content/en/history.html

[26] DiVanna, J. A. 2004. The Future of Retail Banking. New York: Lagrave MacMillan.

[27] European Banking Union. 2012. The EU Single Market, Commission proposals for a single supervisory mechanism. Retrieved from: http://ec.europa.eu/internal_market/finances /banking-union/index_en.htm

[28] Financial Crisis Inquiry Commission. (2011, Jan 25). The Financial Crisis Inquiry Report: Final Report of the National Commission on the Causes of the Financial and Economic Crisis in the United States. Washington, D. C.: Government Printing Office. Retrieved from http://www.gpo .gov/fdsys/pkg/GPO-FCIC/content-detail.html.

[29] Fiordelisi, F. 2009. Mergers and Acquisitions in European Banking. Hampshire, UK: Palgrave-MacMillan.

[30] Gandel, S. 2013. What Buffet deal says about Goldman Sachs,
Fortune \& Money, March 28, 2013. Retrieved from: finance.fortune.cnn.com/2013/03/28/warren-buffett-goldman -sachs/

[31] Gelsi, S. 2001. Citigroup to buy Mexico's Banamex - Weill plunks down $\$ 12.5$ billion for banking giant, Market Watch, May 17, 2001. Retrieved from:www.marketwatch.com/story /citigroup-buys-banamex-for-125billion

[32] Ghemawat, P., Ballarín, E., and Campa, J.M. 2006. Santander's Acquisition of Abbey: Banking Across Borders, Harvard Business School, HBS\#9-707-485, November 2006

[33] Goldman Sachs. 2008. A new playing field: assessing impact of the Itaú Unibanco merger, Global Investment Research, The Goldman Sachs Group, Inc., December 1, 2008

[34] Goldman Sachs Group Inc. 2011. Form 10-K Annual Report of the fiscal year ended December 31. Retrieved from www.goldmansachs.com

[35] Hefferman, S. 2005. Modern Banking. Chichester, England: Wiley and Sons, Inc.

[36] HSBC Press Room. 2011. HSBC to sell its card and retail services business in the US. Newsroom, Aug 10, 2011. Retrieved from www.us.hsbc.com/1/2/home/about/press-roo m/2011/news_08102011_card_sale

[37] HSBC Holdings plc. 2011. Form 20-F Annual Report of 2011. Retrieved from http://www.sec.gov/edgar.shtm.

[38] HSBC Holdings plc. 2002. Form 20-F Annual Report of 2002. Retrieved from http://www.sec.gov/edgar.shtm.

[39] ING Groep N.V. 2011. Form 20-F Annual Report of 2011. Retrieved from http://www.sec.gov/edgar.shtm.

[40] Itaú-Unibanco Holding S.A. 2011. Form 20-F Annual Report of 2011. Retrieved from http://www.sec.gov/edgar.shtm.

[41] JPMorgan Chase and Co. 2011. Form 10-K Annual Report of 2011. Retrieved from http://www.sec.gov/edgar.shtm.

[42] JPMorgan Chase and Co. 2012. 200 Years of Leadership in Banking,http://www.jpmorganchase.com/corporate/About-JP $\mathrm{MC} /$ document/shorthistory.pdf

[43] Kirchfield, A. and Simmons, J., Citi Sells Unit to Credit Mutuel for EU 4.9 billion. Bloomberg, July 11, 2008. Retrieved from http://www.bloomberg.com/apps/news?pid= newsarchives\&sid=a5rgifVkv9Zo

[44] Levy, A. 2009. Wells Fargo Shows New Passion for Investment Banking. Bloomberg, July 29, 2009. Retrieved from

www.bloomberg.com/apps/news?pid=newsarchives\&sid=aN zKTxVP5Mm8

[45] Maude, D. 2006. Global Private Banking and Wealth Management. Chichester, England: Wiley and Sons, Inc.

[46] Marshall, J.F. and Ellis, M. E. 1994. Investment Banking and Brokerage, Chicago, Ilinois: Probus Publishers.

[47] Mayer, M. 1997. The Bankers, The Next Generation. New York: Truman Talley Books/Plume.

[48] Mays, E. 2004. Credit scoring for Risk Managers, Mason, Ohio: Thomson/South Western.

[49] Merced, M.J. 2012, Santander Mexican's Unit Sells U.S. 
Shares at $\$ 12.18$ in Dual Listing, DealBook, New York Times, September 25, 2012. Retrieved from dealbook .nytimes.com/2012/09/25/santanders-mexican-arm-said-to-p rice-its-i-p-o-at-12-18/

[50] Morgan Stanley. 2011. Form 10-K Annual Report for the year ended December 31, 2010. Retrieved from http://www.sec.g ov/edgar.shtm

[51] Patil, D. and Verma, M. 2007. HSBC's Growth Strategy, IBS Case Development Centre, Retrieved from www.ibscdc.org/Case_Studies/Strategy/Growth\%20Strategi es/GRS0256P

[52] Reuters. 2009. Banco Santander's Brazil Unit Raises \$8 billion in I.P.O., October 7, 2009

[53] RTE News Ireland. 2008. €5.5bn bank recapitalisation plan announced. RTE News/Ireland, December 21, 2008. Retrieved from: www.rte.ie.news/2008/1221/111941-bank/

[54] Saltmarsh, M. 2011.. Swiss Near Tax Treaties with Britain and Germany. The New York Times, Aug 9, 2011.

[55] Sinkey, J. 1998. Commercial Bank Financial Management, New Jersey: Prentice Hall.

[56] Sotelino, F. 2011. The Financial Services Industry in The Brazilian State: Debate and Agenda, eds. Font, M. and Randall, L. New York: Lexington Books.

[57] Sterngold, J. 1988, First Boston Merger Brings Sense of Relief,
The New York Times, October 11, 1988. Retrieved from www.nytimes.com/1988/10/11/business/first-boston-mergerbrings-sense-of-relief.html

[58] Story, L. 2008. Morgan Stanley Completes Mitsubishi Deal, The New York Times, 9/29/2008. Retrieved from www.nytimes.com/2008/09/30/business/worldbusiness/30m organ.html? $\mathrm{r}=0$

[59] TD Financial Group. 2011a. Form 20-F Annual Report of 2011. Retrieved from http://www.sec.gov/edgar.shtm.

[60] TD Financial Group. 2011b. Annual Report, Management Discussion and Analysis, Retrieved from: www.td.com.

[61] Thomas Jr., L. 2016. Credit Suisse Boss Faces Revolt From Bankers Over Strategy Shift, The New York Times Deal B\%k, 4 June 2016. Retrieved from

[62] http://news.blogs.nytimes.com/2016/06/06/morning-agenda-c redit-suisse-boss-faces-revolt/? $\mathrm{r}=0$

[63] UBS AG. 2011. Form 20-F Annual Report of 2011. Retrieved from http://www.sec.gov/edgar.shtm.

[64] UniCredit. 2010. Consolidated Report and Accounts, Retrieved from www.unicreditgroup.eu

[65] Venzin, M. 2009. Building an International Financial Firm. Oxford, UK: Oxford University Press.

[66] Wells Fargo and Co. 2011. Form 10-K Annual Report of 2011. Retrieved from http://www.sec.gov/edgar.shtm. 